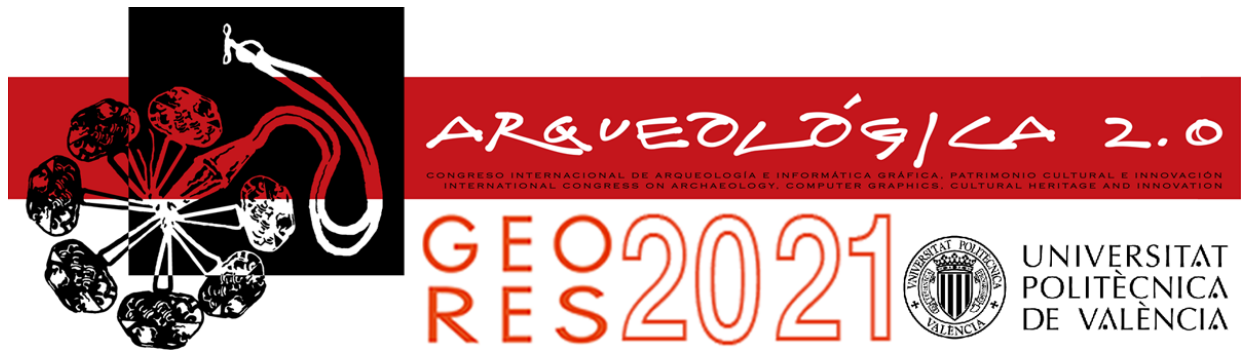

Proceedings of the joint international event $9^{\text {th }}$ ARQUEOLÓGICA

$2.0 \& 3^{\text {rd }}$ GEORES

Valencia (Spain).

26-28 April 2021

\title{
AN INTEGRATION OF NON-DESTRUCTIVE TECHNIQUES (SFM-GPR- TLS) AS A VIRTUAL TOOL FOR ARCHAEOLOGICAL STRATEGY: THE CASE OF THE ROMAN SITE OF THE PLAZA DE LA MORERÍA IN SAGUNTO (SPAIN)
}

\author{
Fernando Buchón-Moraguesa ${ }^{\mathrm{a}}$, Josep Beneditob, Francisco García ${ }^{\mathrm{a},{ }^{*},}$, José Manuel Melchor ${ }^{\mathrm{c}}$ \\ ${ }^{a}$ Department of Cartographic Engineering, Geodesy and Photogrammetry, Universitat Politècnica de València, Camino de Vera s/n, \\ 46022 Valencia, Spain. fbuchon@upv.es; fgarciag@upv.es \\ ${ }^{b}$ Department of History, Geography and Art - Ancient History, Universitat Jaume I, Av. Vicent Sos Baynat s/n, 12071 Castellón de la \\ Plana, Spain. jbenedit@uji.es \\ ${ }^{c}$ Municipal Archaeological Museum, Burriana City Council, Plaza de la Merced s/n, 12530 Burriana, Spain. arqueologo@burriana.es
}

\begin{abstract}
:
In this article, we present a methodology involving a combination of structure from motion (SFM) photogrammetry, ground penetrating radar (GPR) and terrestrial laser scanner (TLS), georeferenced on the same reference frame defined by topographic methods. We show that this simultaneous integration of non-destructive techniques (NDTs) and analysis of archaeological data constitutes a highly effective approach for archaeological research strategies. As an example of the applicability of this framework, we discuss in detail the archaeological research (1991, 2002 and 2018 campaigns) at a Roman site, the Plaza de la Morería, located in the urban area of the city of Sagunto (eastern Spain). The goal of this research was to design a strategy to recover a pre-1 ${ }^{\text {st }}$ century AD Roman funerary space, and to assess whether to remove a $3^{\text {rd }}$ century AD domus pavement covering the funerary remains. We found that our methodology was able to provide an adaptable and flexible design at each phase of the project. The high resolution of 2D and 3D virtual visualisation features of the GPR technique made it possible to pinpoint and map the existence of Roman overlapped horizons and buried structures in the study zone. Therefore, this framework is able to provide a deep understanding of the spatial organisation and stratigraphic potential, allowing informed decisions about which levels to excavate and which ones to remove. This feature is extremely significant for the inherent decision-making process in every archaeological research project, thus opening new perspectives in interventions of location, study, management, conservation and planning in archaeological heritage research.
\end{abstract}

Keywords: virtual-digital archaeology, photogrammetry, structure from motion (SFM), terrestrial scanner laser (TLS), ground penetrating radar (GPR), Roman period, archaeological strategy, 3D virtual visualisation, digital twin

\section{Introduction}

The archaeological site in our study lies in the urban centre of the city of Sagunto (eastern Spain) within a completely urbanised area. The entire urban nucleus of Sagunto is archaeologically protected by urban laws. Specifically, since 2002 various excavation campaigns have been carried out on the site located between Alorco and Huertos streets and Plaza Morería in the city of Sagunto, which is known as the Roman site of Plaza de la Morería (Fig. 1). Archaeological interventions have documented notable construction activity during the Early Roman Empire, with a majority of monumental buildings. These discoveries comprise temple foundations several mausoleums, a Roman road, five domus and the remains of an honorific arch, together with the discovery of sculptural and epigraphic fragments. The site of Plaza de la Morería has recognized importance as it offers a series of stratigraphic and material information that allows confirming the existence of a continuous occupation in this place since the Late Republican period.

Archaeological findings, as has been proven in other Hispanic cities, undoubtedly offer a renewed vision of the evolution and transformation of the city in the transition from the Early Empire to the Late Roman Empire and Late Antiquity (Kulikowski, 2004; Ferrer, Oliver \& Benendito, 2016; Ferrer, Benedito \& Melchor, 2018; Ferrer, Benedito $\&$ Melchor 2020). At the same time, the arrangement of some buildings, the projection of public squares and contemporary terraces has hindered advancements in archaeological research for many years. These conditions, therefore, force us to use methods capable of 
evaluating the potentiality of remains in the subsurface and, as far as possible, technology able to obtain the necessary information without digging up or altering the actual surface. Crucial decisions for the archaeological and historical knowledge of the city of Sagunto may depend on these results.

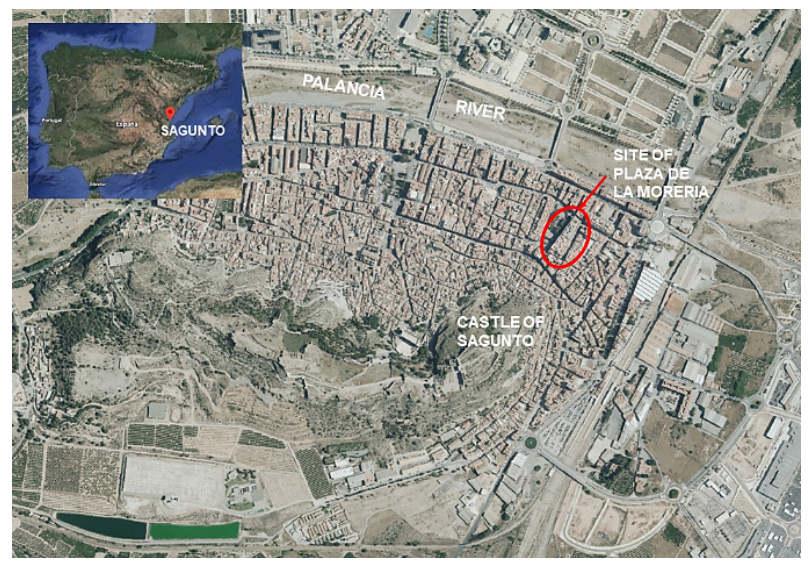

Figure 1: Location of the archaeological site of Plaza de la Morería in the urban area of the city of Sagunto (eastern Spain near the Mediterranean coast).

Archaeological strategy requires accurate techniques for mapping, surface modelling and detecting buried structures in urban areas. Non-destructive techniques (NDTs) integration offers multiple decision making options in archaeological exploration (Puente, Solla, Lagüela, \& Sanjurjo-Pinto, 2018; Malfitana et al., 2015; Horsley, Wright, \& Barrier, 2014; Stal et al., 2014; Lerma, Navarro, Cabrelles, \& Villaverde, 2010).

Because of the results of a previous 2002 site excavation, the existence of funerary remains of the Roman necropolis, still unexcavated, was very likely. The aim of our archaeological research was to recover a section of this pre- $1^{\text {st }}$ century AD Roman funerary space placed under 2 nd and $3^{\text {rd }}$ centuries $A D$ levels. Therefore, a decision-making process of whether to remove the Roman pavement of opus caementicium from an excavated domus from the $3^{\text {rd }}$ century $A D$ covering this funerary space in the eastern part of the site, was necessary. A multidisciplinary approach, involving the integration of several NDT results, was chosen in order to evaluate the existence of pre-1 $1^{\text {st }}$ century $A D$ Roman remains and burial pavement below the Roman pavement of opus caementicium.

A methodology for acquiring three-dimensional data faster, cheaper and more accurate is the photogrammetric correlation (SFM) from terrestrial photographic images (Muñumer, \& Lerma, 2015). This methodology makes it possible to analyse the topographic data of the study area, assess the possible archaeological potential horizon and identify areas of interest.

Geophysics is widely employed for non-invasive studies of underground structures and geological and cultural levels. In the last years, the ground-penetrating radar (GPR) geophysical method has gained increasing importance as the preferred non-invasive method for Cultural Heritage study, due to its high resolution subsurface imagery and 3D data representation, high productivity in collection and recording field data, suitability for high-resolution subsurface imaging. GPR is also remarkable for its accuracy in pinpointing subsurface structures and defining their geometry. These features make the GPR method a more effective means of studying buried structures than other geophysical techniques in archaeological studies (Urban, Murray, Vella, \& Lahikainen, 2015; Conyers, 2013; Leucci \& Negri, 2006; Leckebusch, 2003; Pérez-Gracia et al., 2000). Therefore, the GPR method was proposed to pinpoint Roman underground structures and layers for this study.

The use of the terrestrial laser scanner (TLS) (Kościuk, 2012; Yastikli, 2007) was chosen to document the 2018 archaeological campaign, which was carried out based on SFM photogrammetry and GPR results. A cloud of points was obtained over which the results of the excavation were georeferenced and exposed.

The main objective of this study was to pinpoint the continuity and existence of Roman burial structures and pavement (pre- $1^{\text {st }}$ century AD funerary space) underneath the Roman pavement of opus caementicium from the $3^{\text {rd }}$ century $A D$ in the eastern part of the site. Our study was non-invasive, integrating three-dimensional photogrammetric correlation techniques (SFM), terrestrial laser scanner mapping (TLS) and 3D visualisation of GPR data. Therefore, a suitable archaeological strategy for the recovery of the pre- $1^{\text {st }}$ century $A D$ Roman funerary space was determined, based on the results obtained in the integration of NDTs. A complex and delicate decision had to be made about whether to remove a Roman pavement from the $3^{\text {rd }}$ century $A D$ in order to recover a pre- $1^{\text {st }}$ century AD Roman funerary space.

\section{Sagunto: Historical context in Roman times}

The history of Sagunto is linked to the Iberian oppidum of Arse, located on the hill of Sagunto Castle, on the southern slope of the last foothill of the Sierra Calderona. The first archaeological pieces of evidence of the Iberian population have been located in the western peak in the $6^{\text {th }}$ century $\mathrm{BC}$, but until the end of the $5^{\text {th }}$ century or the first decades of the $4^{\text {th }} \mathrm{BC}$ the construction of the wall on the southern slope is not attested. For its part, the easternmost peak is located in the middle of the coastal plain and from there the control of the passage of the Via Heraclea, the later Via Augusta, as well as the route that runs into the valley of the Palancia River and of the coastline that would practically cover the territory of the Edetana region. In the first half of the $4^{\text {th }}$ century BC Sagunto was a great city on which the coastal settlement of Grau Vell depended. In the following century, the findings have revealed an occupation outside the walls, as indicated by the Iberian ceramics that came to light in the excavation of the site of Plaza de la Morería (Ferrer, Oliver, \& Benendito, 2016; Ferrer, Benedito, \& Melchor, 2018). Roman rule over this enclave intensified since 226 BC. The Ebro Treaty between Carthage and Rome came into force. The classic texts mention the city because it is the scene of confrontations that occurred within the framework of the warlike conflict since $218 \mathrm{BC}$, which ended with the fall of the city the following year. For its part, the news provided on the evolution and transformation of the city has undergone a notable change thanks to the remains that have come to light in the excavations of the Plaza de la Morería. We know that, during the Late Empire, the characteristic urbanism of the 
Roman civitas is in a phase of decline to make way for a new urban model. In this sense, the interventions have made it possible to prove that there is a singular transformation of the buildings that stood out for their public and monumental representation and that the city had built since the Augustus government, that is, some temples, public squares, roads, etc. (Ferrer, Benedito, \& Melchor, 2018). However, written sources, as well as archaeological investigations, provide data that today are insufficient to undertake the complete analysis of the renovation process that affected the city of Sagunto and its territory in Late Antiquity. For this reason, it is not easy to assess the true importance that said city had during the last centuries of Roman domination and the effective control of the Visigoths over the Peninsula, that is, between the middle of the $5^{\text {th }}$ century and the first decades of the $8^{\text {th }}$ century.

The preferential attention in the archaeological investigation of the city of Sagunto for many years was focused on the theatre and the Roman circus. To this must be added the different archaeological interventions that have been carried out in recent years and that have documented a remarkable construction activity. According to the information provided by the excavations, it can be affirmed that Sagunto was organized through various routes that ran through the population to include the Palancia River to the north.

\subsection{Roman site description: Plaza de la Morería}

The excavations carried out on the site of the Plaza de la Moreria in the 2002 campaigns confirmed the existence of levels of occupation since the end of the Republican period and ceramic finds from the Iberian period. On the other hand, remains ascribed to funeral constructions related to cremation burials have been documented, whose grave goods have been dated to the JulioClaudian period (Melchor, Benedito, \& Ferrer, 2015). The next construction phase dates back to the end of the $1^{\text {st }}$ century, among whose remains stand out the foundations of a temple, the arcaded road and the bases of an honorific arch (Ferrer, Benedito \& Melchor, 2018).

The archaeological intervention carried out in the Plaza de la Morería, in 2002, revealed the main road axis of communication with the interior of the city, with a northsouth orientation. It is a paved and road's portico, while several funerary monuments were built on its eastern flank. This road completes another paved street, this time with an east-west direction, located a few meters away (Fig. 2).

During the Late Empire, the characteristic urbanism of the Roman civitas gave way to a new urban model, where the public buildings that had been erected in the city since Augustus was being distorted. The domus followed new residential models, while the provision of new constructions led to the transformation of urban planning from the Early Roman Empire.

In the $3^{\text {rd }}$ century, five domus were built next to the road which paid off the cemetery area and part of the structures built in the $2^{\text {nd }}$ century. The extension of the area for housing meant the opening of new drains, the construction of fountains, the closing of the portico and the occupation of the sidewalk to use the scarce surface available. The location of these environments, then barely known in Sagunto, opened a new vision of the processes of change that manifested in the urban environment in Roman times (Melchor, 2013) (Fig. 3).

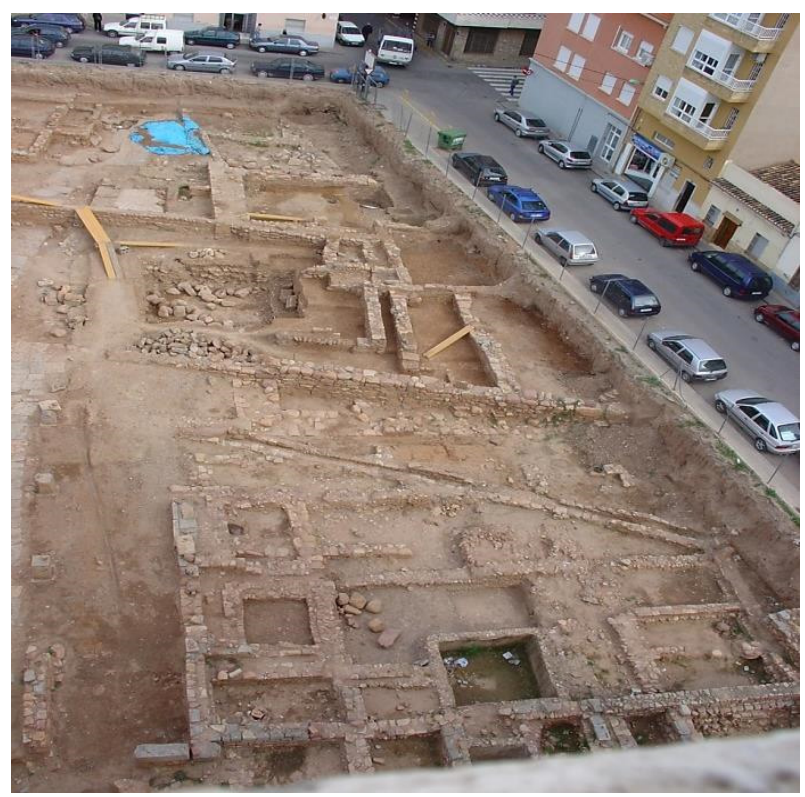

Figure 2: A photograph showing the Roman structures excavated at the Plaza de la Morería site from the 1991 and 2002 archaeological campaigns.

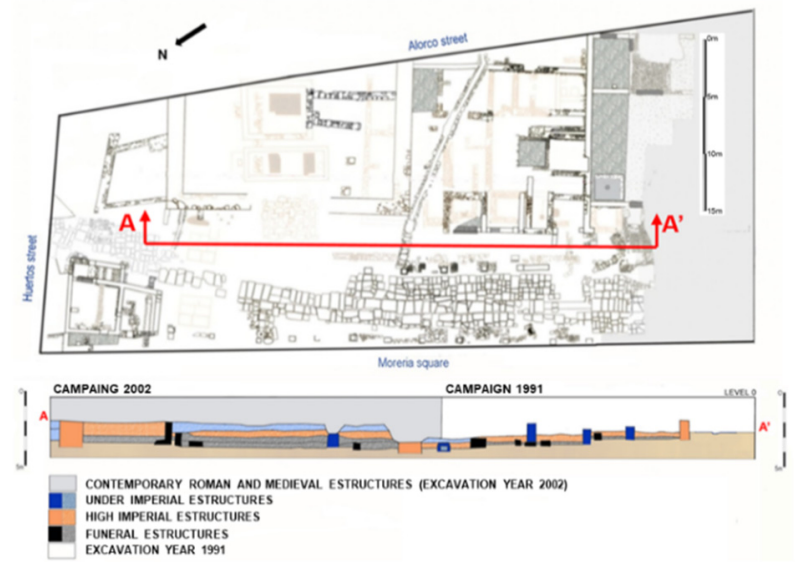

Figure 3: A section view A-A' of the excavation in the Plaza de la Morería site.

Since Late Antiquity, the city has offered a decadent image, a circumstance that can be seen in a decline in urban development. Some of the roads were disabled, the domus located outside the walls were abandoned and, finally, the habited area was contracted. In the $5^{\text {th }}$ century, looting phenomena of Roman structures and extensive levels of collapse appeared covering practically the whole surface occupied by the domus, a process that culminated in the use of part of the sewer as a burial necropolis. This new urban scheme would leave almost the entire old residential area in the lower part of Sagunto uninhabited and including the Plaza de la Morería site. 


\section{Non-destructive techniques}

\subsection{Structure from motion (SFM) photogrammetry}

In order to have a first topographical approximation of the study area, the SFM (Structure from Motion) photogrammetry was chosen to obtain a threedimensional model of the study area environment, using photographic images supported by surveying points measured on the ground.

The camera used for the photogrammetric survey was the Canon EOS-1Ds Mark III, with a focal length of $35 \mathrm{~mm}$, a resolution of $5,616 \times 3,744$ pixels and a pixel size of $6.41 \times 6.41$ microns. And a SOUTH NTS-330 total station was used for the surveying measurements. A local system of coordinates was defined from the surveying measurements, on which all the subsequent work will be georeferenced.

Prior to taking the photographic images, a total of $6 \mathrm{~B} / \mathrm{W}$ objectives were placed on the pillars of the building, in whose basement the ruins under study are located, and they were given three-dimensional coordinates using a topographic total station. The distribution of terrestrial photographic shots was made in a random way given the difficulty of making linear passes through the characteristics of the terrain, at all times the principles of photogrammetry were maintained in terms of overlap between consecutive photographs. Each photograph taken had a high percentage of overlap with the previous and subsequent photograph and the route of the photographic shots was carried out in a perimeter way to the study area, densifying the number of photographs in those areas that suggested greater interest. Figure 4 shows the distribution of the 189 photographs taken.

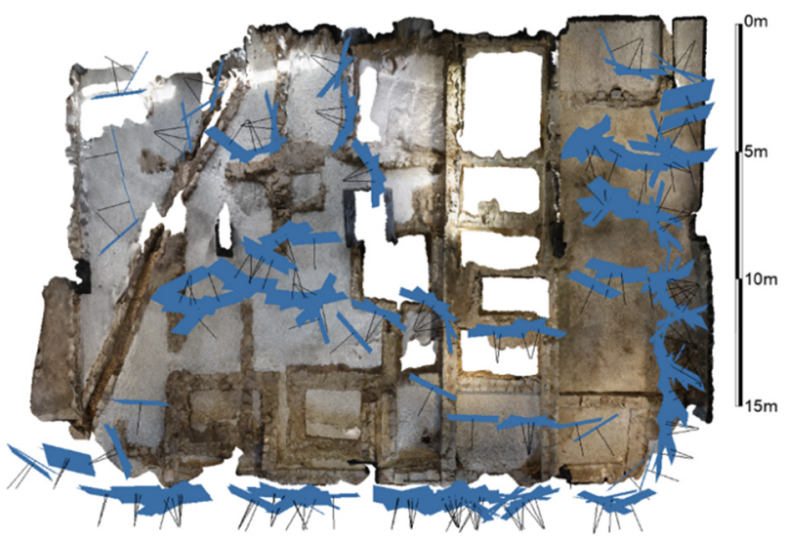

Figure 4: Distribution of each of the positions (blue) and orientations (black lines) of the photographic shots.

The calculation of the three-dimensional point cloud and its texturing was executed with the Agisoft Metashape Professional program and its georeferencing was carried out from the $6 \mathrm{~B} / \mathrm{W}$ targets distributed in some of the pillars of the work area and of which its topographic coordinates are known. The error obtained in the absolute orientation of the model was $0.016 \mathrm{~m}$. The number of three-dimensional points obtained was $24,371,568$, which have been used to construct a digital model of the terrain with $1,610,380$ triangles and a point density of 9.69 points per square centimetre.
The archaeological site three-dimensional model purpose (Fig. 5) was to check the levels in each of the enclosures defined by the wall uprights. In this way, two burial sites were identified with heights of $9.85 \mathrm{~m}$ and $10.37 \mathrm{~m}$ according to our local reference system (AA') and the height of the opus caementicium pavement of the $3^{\text {rd }}$ century $A D$ which is $10.65 \mathrm{~m}\left(\mathrm{BB}^{\prime}\right)$. Figure 6 identifies these levels on the orthophoto of the site and the section made by the areas of interest, clearly showing that the $3^{\text {rd }}$ century $A D$ pavement is $0.28 \mathrm{~m}$ and $0.85 \mathrm{~m}$ above the identified burial sites. This led us to consider the existence of a potential archaeological horizon under the $3^{\text {rd }}$ century $A D$ pavement which should be analysed with the GPR technique.

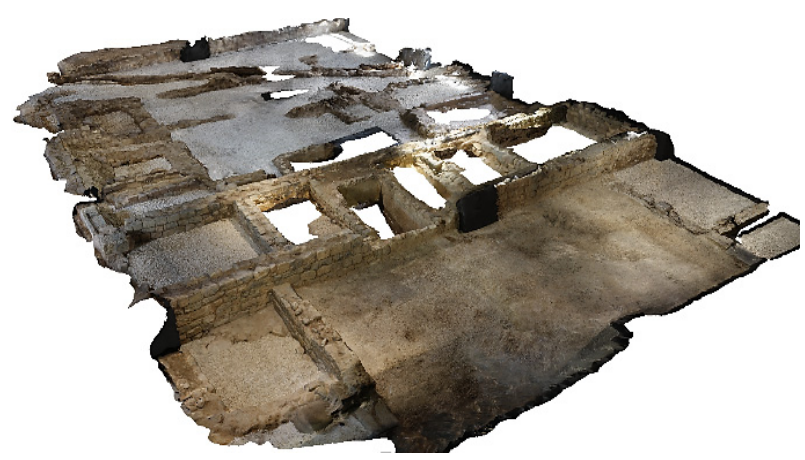

Figure 5: Textured 3D model obtained from the archaeological site of Plaza de la Morería by photogrammetry (SFM).

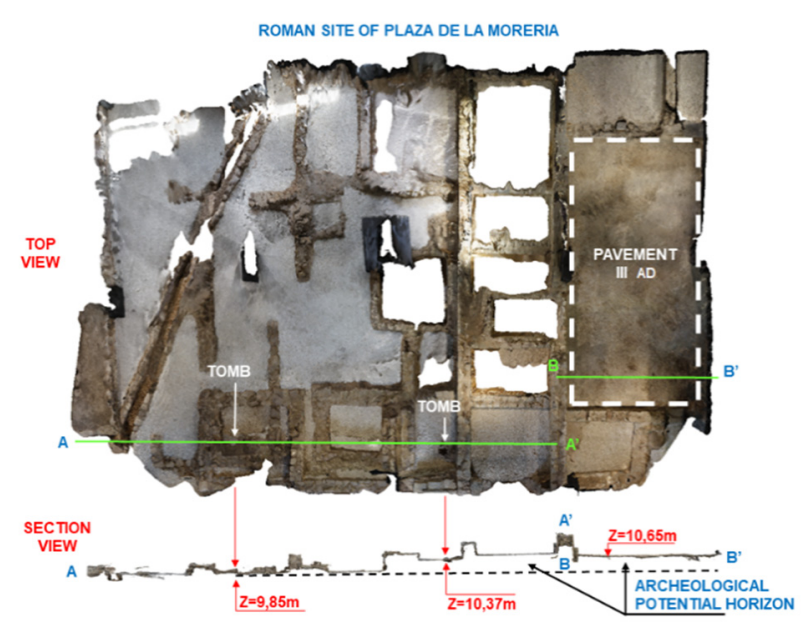

Figure 6: Orthophoto of the site plan and the section made where the existence of a potential archaeological horizon is inferred under the pavement of opus caementicium from the $3^{\text {rd }}$ century AD.

\subsection{GPR technique}

\subsubsection{Field data acquisition}

Data collection was required for the whole of the Roman pavement of opus caementicium under study. Threedimensional (3D) GPR methodology was carried out to pinpoint and define the continuity and existence of pre- $1^{\text {st }}$ century $A D$ Roman burial structures and pavement, according to the results from depth analysis of the archaeological layers in the cross section obtained by SFM. A rectangular grid $(10.50 \times 5 \mathrm{~m}$ size $)$, with equidistant orthogonal 2D lines, spaced every $0.50 \mathrm{~m}$, was designed for the data acquisition on the Roman pavement of opus caementicium. This rectangular grid was topographically 
georeferenced to the local system previously defined with the SOUTH NTS-330 total station. Each beginning and end of the profiles were marked with chalk on the ground. Once marked, an elastic tape was extended between the beginning and end chalk marks of each 2D GPR profile in order to follow precisely the corresponding line. The GPR data were collected with a GSSI SIR-3000 device. Considering that the average depth of study for pre-1 $1^{\text {st }}$ century AD Roman funerary space was around $2 \mathrm{~m}$, a nominal $400 \mathrm{MHz}$ centre frequency antenna was used. The data acquisition was carried out in the continuous mode with trace-interval of $0.02 \mathrm{~m}$, a total time window (range) of 60 ns and defined by 512 samples per trace for a total of 33 profiles (22 transversal and 11 longitudinal profiles), as shown in Figure 7. A survey wheel (encoder) was attached to the side of the GPR antenna. Thus, it was possible to record GRP profiles $0.15 \mathrm{~m}$ from the perimeter walls that framed the studied pavement. Due to the fact that the Roman pavement of opus caementicium was flat with no unevenness or slopes, the survey wheel tracked the distance travelled and allowed consistent scan spacing in order to calculate trace-interval distance.

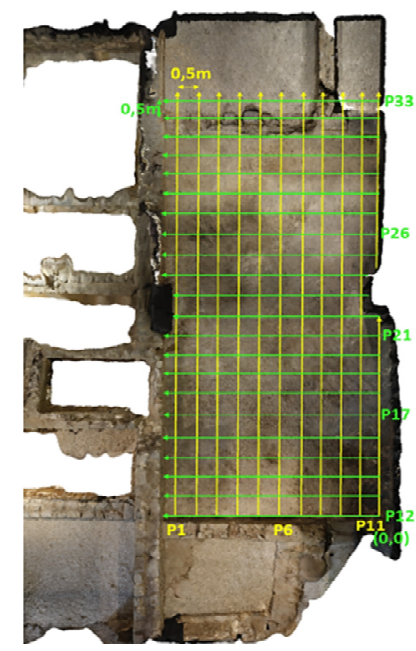

Figure 7: Layout of the GPR profiles in a grid $0.50 \times 0.50 \mathrm{~m} \mathrm{(22}$ transversal and 11 longitudinal profiles) on the Roman pavement of opus caementicium of $3^{\text {rd }}$ century AD.

The GPR reflection data were acquired on the same day. Therefore, the subsurface moisture conditions of this investigated sector could be considered almost constant for the investigated depth during the acquisition of GPR field data. This velocity estimation assumption was made for the proposed objective of locating the Roman burial structures and pavement underneath the Roman opus caementicium pavement from the $3^{\text {rd }}$ century $A D$, with consideration to the fact that possible changes in the subsurface conditions could cause velocity variations which that would affect velocity-to-depth conversions. The average velocity of the GPR wave was determined by using the hyperbola fitting method in a set of hyperbolas recorded in different profiles, obtaining an average velocity value $8.5 \mathrm{~cm} / \mathrm{ns}$. The dielectric permittivity was calculated to be 12.5 , according to the following Eq. (1) (Conyers, 2013):

$$
\varepsilon=\left(\frac{c}{v}\right)^{2}
$$

where

$$
\begin{aligned}
\varepsilon & =\text { dielectric permittivity } \\
v & =\text { electromagnetic wave velocity } \\
c & =\text { velocity of light in free space }(c \approx 29.97 \mathrm{~cm} / \mathrm{s})
\end{aligned}
$$

Windows were converted to depth using the same dielectric permittivity at all times. This value was applied for calculation of the processed depths in the investigated sector. This average velocity was also used in Kirchhoff migration for the processing of the 2D GPR data.

\subsubsection{Data processing}

Prior to the construction of a rendered three-dimensional image with all reflection profiles in a grid, post-acquisition processing procedures are required for application to the GPR raw field data set. There are several post-acquisition radar signal processing techniques that can potentially be used for GPR datasets depending on their objectives. In this study, a basic data processing procedure was applied to the raw data set using the RADAN software developed by Geophysical Survey Systems, Inc. (GSSI), due to the fact that good signal penetration in the reflection profiles.

As a first step, the zero-time correction, background removal and gain function were also applied to amplify the received signal and improve the reflection identifications. Raw 2D data was also processed by applying filters such as the Kirchhoff migration filter using average velocity for diffraction removal. A GPR-3D model of the subsurface was obtained by aligning processed $2 \mathrm{D}$ profiles to accurately locate the burial structures and evidence of pavement underneath the sector studied. In addition, a transparent visualisation of the 3D GPR data set was carried out to reveal the main structures of the subsurface.

\subsubsection{Results}

The 2D radar profiles provide an overview of the area under the study of the archaeological site. These radar profiles illustrate the dissimilarities of the subsurface. The profiles show main anomalies of interest (Roman structures) from meters 0 to 7.50 and from meters 8.70 to 10.50 at depths from meters from 0.27 to 0.85 . Besides, deeper anomalies observe from meters 0 to 7.50 and from meters 8.70 to 10.50 at depths from meters from 0.88 to 2.20 (Iberian structures), as shown in Figure 8a. These anomalies reveal the presence of Roman and Iberian structures in the studied volumetric space. Additionally, the existence of strong linear reflector is observed at depth $0.80-0.88 \mathrm{~m}$ that corresponds to pre- $1^{\text {st }}$ century $A D$ burial pavement. These GPR results correspond to the results of the 2002 archaeological campaign and the cross-analysis of the depths of archaeological layers obtained by SFM.

Determining geometrical and dimensional features of Roman structures derived from GPR 2D data is timeconsuming and requires an individual analysis of every radar profile. 3D GPR visualisation techniques overcome this drawback by defining the buried remain features for the entire studied underground volume, as shown in Figure 8b.

Further, the isosurface rendering technique allowed displaying surfaces of equal amplitude in the studied volume. Specifically, this 3D GPR data visualisation 
reproduces and highlights the geometric characteristics of the reflections, derived from archaeological remains, with a strong contrast to the surrounding environment of the analysed volume. This isosurface image was coloured purple-magenta to show these amplitude values, while others were made transparent to better represent only the archaeological remains and simplify their detection and interpretation of the data. The transparent visualisation of the 3D GPR data set was conducted in order to reveal the main anomalies of interest (Roman structures and layers) in the studied volume. The obtained isosurface image allowed the three-dimensional visualisation of the most relevant Roman structures and layers defined in the volume from 0.20 to $0.88 \mathrm{~m}$ depth and also the Iberian remains in the volume from 0.88 to $2.20 \mathrm{~m}$ depth, as shown in Figure 8c.

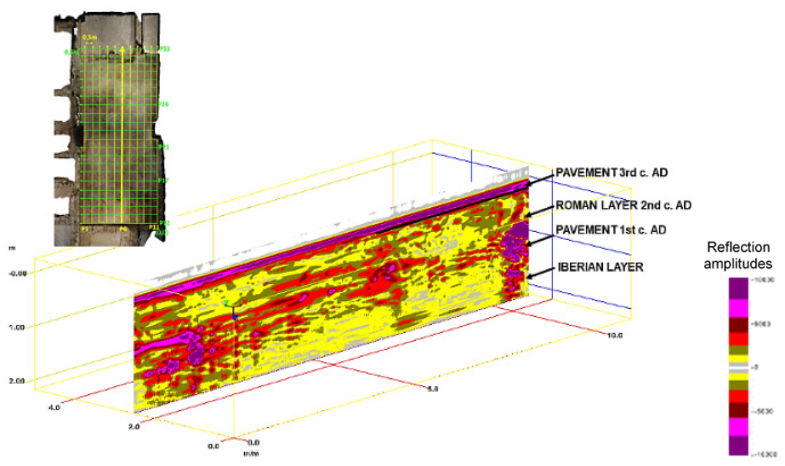

(a)

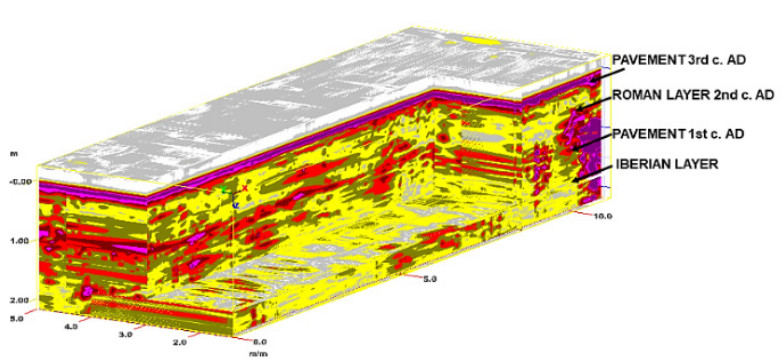

(b)

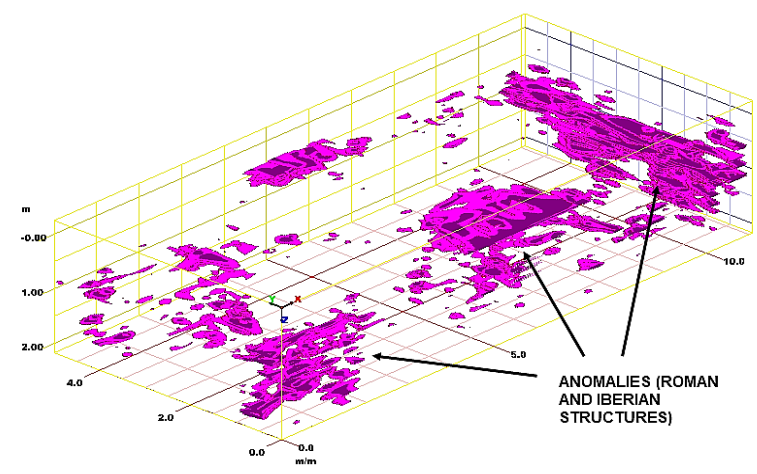

(c)

Figure 8: Overview of the area under the study of the archaeological site: a) P6 reflection profile; b) 3D radar section images after processing the raw data, showing strong underground evidence of Roman and Iberian structures and layers; c) Isosurface image in the volume under study, showing the main anomalies (Roman and Iberian structures) detected and other reflection points.
As seen in Figure 8, the main recorded anomalies (Roman and Iberian structures) are concentrated in the southern, central and northern areas of the volumetric space under study.

It should be noted that the evidence of the continuity of the pre- $1^{\text {st }}$ century $A D$ burial pavement had been pinpointed at a depth of $0.85 \mathrm{~m}$. This information was crucial for determining which archaeological strategy was required in order to recover the Roman funerary space at the Plaza de la Morería site.

\subsection{Integration of SFM photogrammetry and GPR techniques}

Because the origin and final coordinates of each of the profiles made with the GPR are known, it is straightforward to integrate these profiles into the terrain's photogrammetric correlation digital model. The 3D photogrammetric model data integration with the 2D GPR profiles and the 3D GPR mode was carried out using AutoCAD software. Figure 9 shows the representation of the longitudinal profile P6 in its exact position, as in the area of the pavement studied (opus caementicium from the $3^{\text {rd }}$ century $A D$ ), it can be seen that the thickness is continuously $0.20 \mathrm{~m}$, the existence of anomalies between $0.88 \mathrm{~m}$ and $2.20 \mathrm{~m}$ can also be seen in the initial zone of the profile and in the final part of the profile it can be seen how the surface wall presents a response in depth which reaches $2.10 \mathrm{~m}$

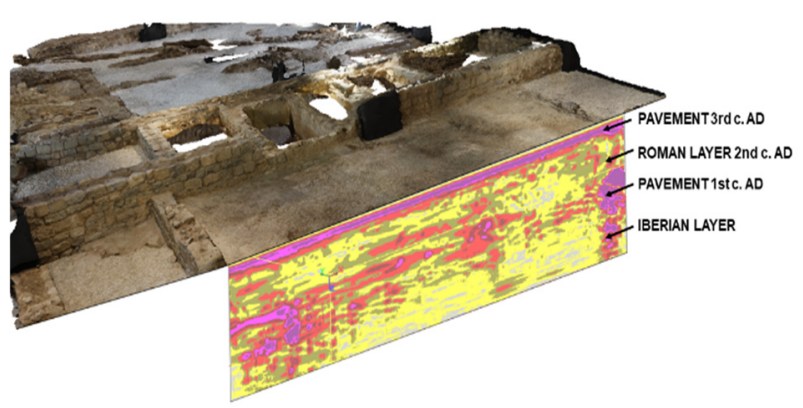

Figure 9: $\mathrm{P} 6$ reflection profile georeferenced in the digital model of the terrain of the Plaza de la Morería site, which shows underground evidence of Roman and Iberian structures and layers along the profile.

Using the same methodology, the profiles have been integrated into the digital model of the terrain in order to have a better interpretation of the GPR three-dimensional data in the volume studied. The superposition result is presented in Figure 10, where the thickness of $0.20 \mathrm{~m}$ of the pavement from the $3^{\text {rd }}$ century $A D$ and the continuity of the pre- $1^{\text {st }}$ century $A D$ funerary pavement is apparent.

\section{Archaeological strategy}

It was conjectured, by results obtained in 2002 in the excavation of a different $2^{\text {nd }}$ century AD building within the site previously excavated in 1991, that it was likely that archaeological strata existed below the excavated remains, similar to those documented on the north flank of the site where the base of a temple came to light, as shown in Figure 11. Therefore, in the process of defining an archaeological strategy to recover the funerary space that existed until the $1^{\text {st }}$ century $A D$ at the Plaza de la Morería, it was essential to determine the extent and entity of the archaeological remains located in the 
subsurface, in order to be able to relate them to the findings already excavated in the 1991 and 2002 campaigns.

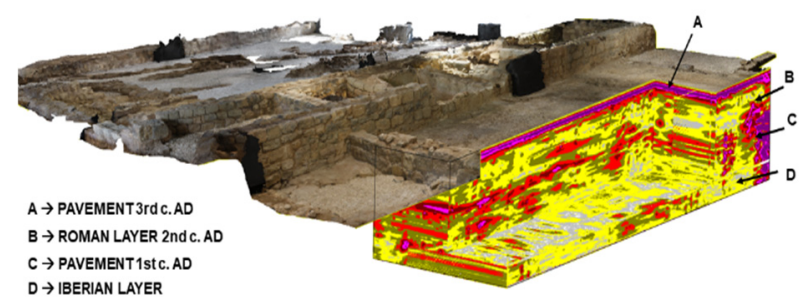

Figure 10: 3D GPR model georeferenced in the digital model of the terrain obtained in the Plaza de la Morería site, which shows underground evidence of Roman and Iberian structures and layers in the volumetric space studied under the Roman pavement of opus caementicium from the $3^{\text {rd }}$ century $A D$.

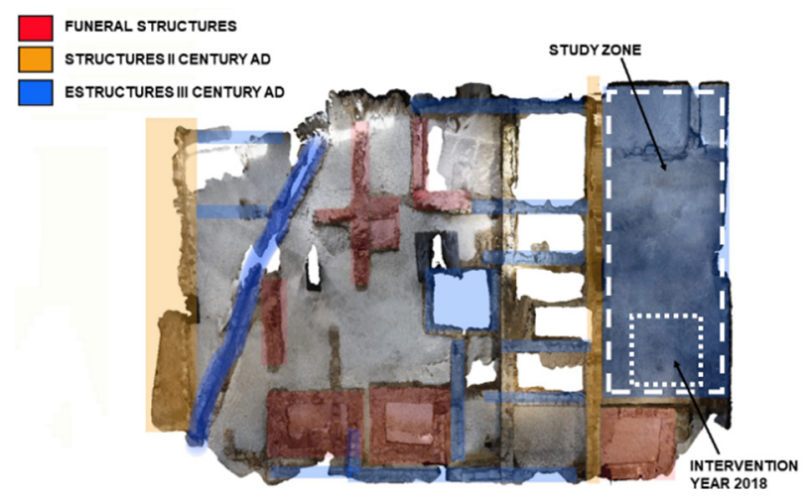

Figure 11: Archaeological intervention area in the 2018 campaign (white dotted line) following the decision made based on the results obtained in the SFM photogrammetry and GPR in the study area (white dashed line).

The integration of data from non-destructive SFM and GPR techniques, combined with archaeological data represent an important potential in archaeological research project strategies where the overlap of cultural levels is present, especially in urban areas that may continue in the subsurface.

The integration of SMF and GPR allowed determining the main area (concentration of Roman structures and the presence of the funerary pavement) with the greatest stratigraphic power. This integration specified that part of the structures from the Roman period, such as the roads and monumental buildings, had continuity in the immediate space. In addition, it was detected that the walls of the domus were on other previous structures that had the same arrangement. The existence of other structures sub posed to the funerary levels within the site was also recorded, therefore it was very likely that the structures could have a Late Republican or Iberian chronology.

Consequently, it was possible to demonstrate that there were pre- $1^{\text {st }}$ century AD Roman funerary remains below the $2^{\text {nd }}$ century building. These remains were covered by a $3^{\text {rd }}$ century opus caementicium pavement, corresponding to a floor of the domus using part of the structure of the monumental building.

After analysis and evaluation of the integrated SFM and GPR results, the decision was made to recover the pre$1^{\text {st }}$ century $A D$ Roman funerary space by removing the paving of a $3^{\text {rd }}$ century $A D$ domus and the Roman structures from the $2^{\text {nd }}$ century that covered it. As a result, a new archaeological intervention was proposed specifically in the southern area of the $3^{\text {rd }}$ century $A D$ pavement.

\subsection{Archaeological intervention}

The new archaeological campaign was carried out in January 2018. Work was carried out on the excavation of the stratigraphy in an archaeological survey of approximately $3 \times 3 \mathrm{~m}$ where a greater presence of archaeological structures and a possible funerary pavement had previously been detected by GPR (Fig. 11).

First, the opus caementicium paving covering this space was removed. The soil was composed of a $0.06 \mathrm{~m}$ layer of lime mortar, sand and gravel and a pebble preparation that was $0.14 \mathrm{~m}$ thick. From this pavement, some fragments of common pottery and tegulae mixed with the caementicium were recovered. Below the pavement, a layer of $0.22 \mathrm{~m}$ of depth was registered, formed by the earth of a clay composition of beige colour, very compact, and little ceramic and bone material. Among the materials, the presence of very small fragments of limestone with a blackish hue stood out above all, which due to their characteristics could correspond to the remains of the carving of the stones that were part of the walls of the building linked to the caementicium pavement. It could be a level of compaction and levelling of said soil. The next layer had an archaeological power of $0.43 \mathrm{~m}$ and corresponded to a stirred level. Many large stones and bowls, other small and medium-sized stones, abundant fragments of stone and ceramic material were documented. Among the ceramics, the presence of amphora, dolia and tegulae fragments stands out. Only next to the south cut of the excavation did there appear caked edges with a certain orderly arrangement, which could indicate the presence of a wall. During the excavation process of this level, it was observed that it amortized a large pebble wall of which $0.45 \mathrm{~m}$ in height was preserved. This was under the structures of the superimposed building and had attached the remains of a pavement preparation, which was composed of a layer of lime and a compacted level of clay soil and gravel. This unit had a thickness of $0.08 \mathrm{~m}$. Likewise, this pavement appeared associated with a small circular pit. In the eastern sector of the table, a $0.28 \mathrm{~m}$ diameter pit affected its conservation.

Finally a $0.40 \mathrm{~m}$ strip was excavated in the section where the pavement was not preserved, in the southern part of the excavation, which allowed reaching a stratum of sandy composition and $0.30 \mathrm{~m}$ of stratigraphic power, with few ceramic materials from the Iberian period.

\subsection{Results of the archaeological intervention 2018}

The excavation revealed that the caementicium pavement covered a mixed level, in which the remains of various foundations appeared: very roughly carved pebbles and stones, squared stone fragments and slab fragments that were probably part of a pavement that was not preserved (Fig. 12). We also recorded abundant ceramic material, especially brick material, fragments of amphorae and Iberian ceramics, and to a lesser quantity 
of sigillata and thin-walled pottery. The chronology of this material varies between the $2^{\text {nd }}$ century $B C$ (fragments of Iberian pottery, Greco-Italian and Punic pottery) to the $1^{\text {st }}$ century AD (Roman thin-walled pottery, Italic and South Gaulish terra sigillata). This chronology could indicate that, at this time, a remarkable transformation of the terrain took place that undoubtedly affected the basal structures. In this sense, the works brought to light the preparation of a floor, fragments of stone slabs with lime mortar residue and a small circular pit, which might be a hole for a roof support post. This pavement was attached to a wall beneath the $2^{\text {nd }}$ century AD structures, coinciding with the closure of a structure excavated in 1991. The pavement was located below the structures of the 2 nd and $3^{\text {rd }}$ centuries $A D$, next to the road. It is, therefore, a structure dating from before the $2^{\text {nd }}$ century $A D$, which can be related to the funerary levels of the site. The fact that many stone fragments from opus vittatum walls appeared in the filling that amortized this structure, may suggest that the funerary level is inside the $2^{\text {nd }}$ century structure.

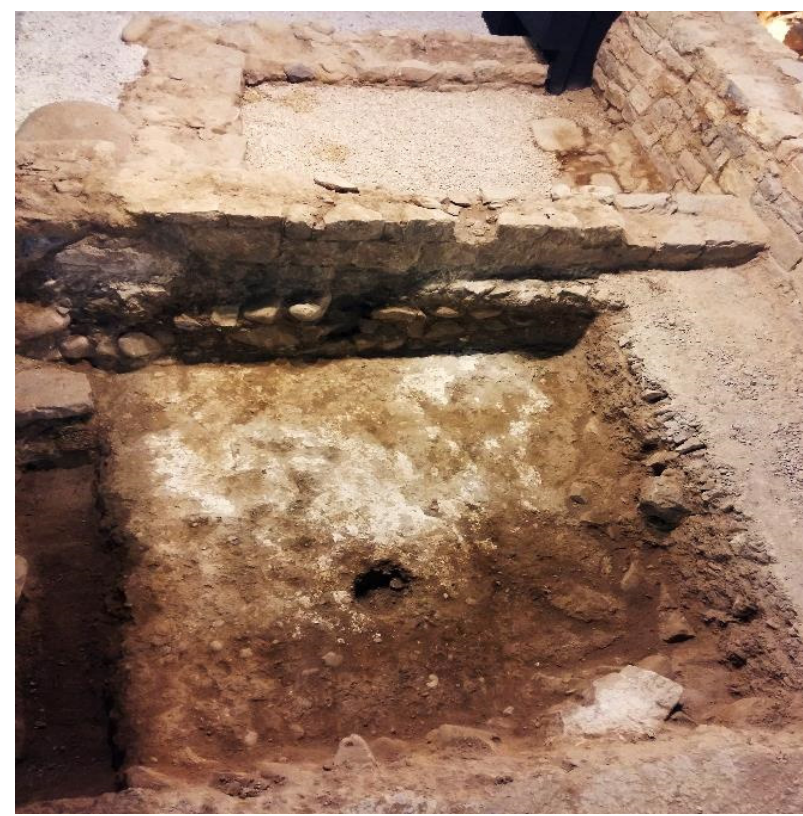

Figure 12: A photograph of the entire plan of the funerary space after the 2018 archaeological intervention, showing the pre- $1^{\text {st }}$ century AD funerary pavement and the circular pit previously detected in the GPR geophysical survey.

\section{Digital documentation: terrestrial laser scanner (TLS)}

Documentation of the results of the 2018 archaeological campaign was completed with a topographical survey of the final state of the prospection using a terrestrial laser scanner (TLS). The instrument used was the TRIMBLE TX-6.

The main reason for using a terrestrial laser scanner (TLS) for digitally documenting the results is that the TLS was also used in a previous 2018 campaign to digitize the interior and exterior of the archaeological site area. Thus, the corresponding digital documentation data obtained in this study could be combined with those of the previous campaign.

The point cloud obtained was georeferenced on the local system of coordinates used in the studies prior to the tasting. Measurements were also made on targets outside of which the coordinates are known in UTM projection, datum ETRS-89, zone 30, orthometric height, in order to be able to materialise all the three-dimensional metric products made in this work on an absolute coordinate system.

The main advantage of working with laser scanners is that the three-dimensional model generated is incorporated into the final file, and at any time afterwards, the necessary measurements can be obtained. However, the stratigraphy obtained because of the 2018 intervention was incorporated into the archaeological dossier, as shown in Figure 13.

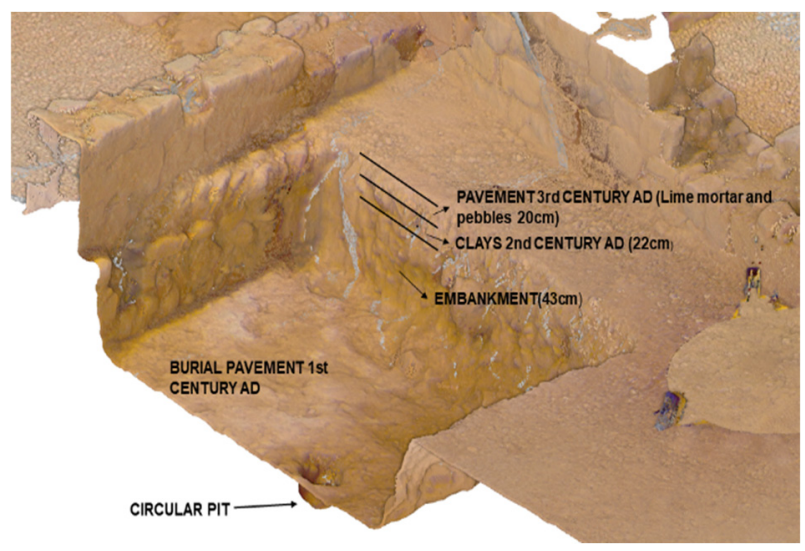

Figure 13: Stratigraphy obtained because of the 2018 archaeological intervention georeferenced in the 3D laser scanner model of the Plaza de la Morería site.

\section{Conclusions}

The archaeological interventions that were carried out on this site in 1991 and 2002 proved the existence of very interesting structures from the early imperial period. The original plan was rectangular, with opus vittatum walls, while in the $3^{\text {rd }}$ century AD the foundations of a domus were attached to the northern wall. Inside, a caementicum floor was documented, three rooms on the west façade and another on the east façade, facing the road.

The GPR and SFM results first indicated, and then revealed, the existence of structures below the pavement. These results were later corroborated by the remains documented in the archaeological excavation of 2018 without appreciable deviations. Furthermore, a laser scan inventory was carried out of the funerary space of the Plaza de la Morería site, the only one preserved so far in the city. This laser scan inventory cleared the way for relating the funerary remains from the 2018 excavation with those of the previous campaigns present on the site at a topographic and spatial level, through the stratigraphic correlation and orientation of various monuments.

As a consequence of this multidisciplinary intervention, the 2018 archaeological campaign has recovered the floor plan of a funerary monument from the High-Imperial period, the loculus, and the remains of the pavement of the possible pre-1 ${ }^{\text {st }}$ century access area. At the time of this publication, this is the only funerary monument from the Early Roman Empire period visible in the city of Sagunto. This funerary complex was masked by structures from a later period, specifically from the 2nd and $3^{\text {rd }}$ centuries AD. Currently, after delimitation and excavation, it serves as an example not only for the 
understanding and interpretation of the other funerary monuments in Plaza de la Morería, but also for the general mapping of the necropolis and its interaction with the other levels and period. This funerary complex also opens the door to further research into the pre-Roman levels and strata (Iberian horizons) underneath this Roman funerary complex.

In summary, we have shown that our methodology of detection, documentation, mapping and $3 D$ restitution, based on the integration of SFM photogrammetry, GPR and TLS, is an efficient virtual tool in the decision-making process and other decisions made in phases of archaeological prospecting and intervention (both excavation and conservation). In addition, due to its flexibility and capacity to obtain information for analysis, digital mapping and 3D surface and subsurface virtual visualisation, this methodology can serve as a model for other sites with different geographical characteristics and chronologies, both in urban and rural areas.

\section{Acknowledgements}

The authors are grateful to Sagunto Town Council for funding the archaeological excavation work in 2018.

\section{References}

Conyers, L. B. (2013). Ground-Penetrating Radar for Archaeology. Third edition. Altamira Press, Walnut Creek, California.

Ferrer, J. J., Benedito, J., \& Melchor, J. M. (2018). A New Impression of the Roman City of Saguntum (Spain) Based on Recent Findings. Archeologia Classica, 69, 357-72. https://doi.org/10.1400/267461

Ferrer, J. J., Benedito, J. \& Melchor, J. M. (2020). Saguntum: The Remains of an Honorary Arch and Urban Planning Outside the City Walls. European Journal of Archaeology, 23(1), 43-63. https://doi.org/10.1017/eaa.2019.43

Ferrer, J. J., Oliver, A., \& Benedito, J. (2016). Saguntum y La Plana. Una ciudad romana y su territorio. Publicacions Diputació de Castelló, Castellón.

Horsley T., Wright A., \& Barrier C. (2014). Prospecting for New Questions: Integrating Geophysics to Define Anthropological Research Objectives and Inform Excavation Strategies at Monumental Sites. Archaeological Prospection, 21, 75-86. https://doi.org/10.1002/arp.1476

Kościuk, J. (2012). Modern 3D scanning in modelling, documentation and conservation of architectural heritage. Wiadomości Konserwatorskie, 82-88.

Kulikowski, M. (2004). Late Roman Spain and its Cities. Baltimore et Londres. Johns Hopkins University Press.

Leckebusch, J. (2003). Ground-penetrating Radar: A Modern Three-dimensional Prospection Method. Archaeological Prospection, 10, 213-240. https://doi.org/10.1002/arp.211

Lerma, J. L., Navarro, S., Cabrelles, M., \& Villaverde, V. (2010). Terrestrial laser scanning and closerange photogrammetry for 3D archaeological documentation: The Upper Palaeolithic Cave of Parpalló as a case study. Journal of Archaeological. Science, 37, 499-507. https://doi.org/10.1016/j.jas.2009.10.011

Leucci, G., \& Negri, S. (2006). Use of ground penetrating radar to map subsurface archaeological features in an urban área. Journal of Archaeological Science, 33, 502-512. https://doi.org/10.1016/j.jas.2005.09.006

Malfitana, D., Leucci, G., Fragalà, G., Masini, N., Scardozzi, G., Cacciaguerra, G., Santagati, C., \& Shehi, E. (2015). The potential of integrated GPR survey and aerial photographic analysis of historic urban areas: A case study and digital reconstruction of a Late Roman villa in Durrës (Albania). Journal of Archaeological Science: Reports, 4, $276-284$. https://doi.org/10.1016/j.jasrep.2015.09.018

Melchor, J. M. (2013). El poblamiento romano en Saguntum y su territorium: organización urbana y explotación agrícola. Tesis Doctoral inédita. Castellón: Universitat Jaume I.

Melchor, J. M., Benedito, J., \& Ferrer, J. J. (2015). Una nueva necrópolis augústea en Sagunto. Los monumentos funerarios de la plaza de la Morería. In J. López-Vilar (Ed.), Tarraco Biennal. 2 Congrés internacional d'arqueologia i món antic (pp. 239-245).

Muñumer, E., \& Lerma, J. L. (2015). Fusion of 3D data from different image-based and range-based sources for efficient heritage recording. Digital Heritage, 1, 83-86. IEEE. https://doi.org/10.1109/DigitalHeritage.2015.7413840

Pérez-Gracia, V., Canas, J. A., Pujades, L. G.; Clapés, J., Caselles, O., García, F., \& Osorio, R. (2000). GPR survey to confirm the location of ancient structures under the Valencian Cathedral (Spain). Journal of Applied Geophysics, 43, 167-174. https://doi.org/10.1016/S0926-9851(99)00056-7

Puente, I., Solla, M., Lagüela, S. \& Sanjurjo-Pinto, J. (2018). Reconstructing the Roman Site "Aquis Querquennis" (Bande, Spain) from GPR, T-LiDAR and IRT Data Fusion. Remote Sensing, 10(3), 379. https://doi.org/10.3390/rs10030379

Stal, C., Van Liefferinge, K., De Reu, J., Docter, R., Dierkens, G., De Maeyer, P., Mortier, S., Nuttens, T., Pieters, T., van den Eijnde, F., van de Put, W., \& De Wulf, A. (2014). Integrating geomatics in archaeological research at the site of Thorikos (Greece). Journal of Archaeological Science, 45, 112-125. https://doi.org/10.1016/j.jas.2014.02.018

Urban, T. M., Murray, C. A., Vella, C., \& Lahikainen, A. (2015). Ground-penetrating radar survey on the island of Pantelleria (Italy) reveals an ancient architectural complex with likely Punic and Roman components. Journal of Applied Geophysics, 123, 164-169. https://doi.org/10.1016/j.jappgeo.2015.10.012 
Yastikli, N. (2007). Documentation of cultural heritage using digital photogrammetry and laser scanning. Journal of Cultural Heritage, 8, 423-427. https://doi.org/10.1016/j.culher.2007.06.003 